\title{
Analisis Kemampuan Pemecahan Masalah Matematis : Dampak Metode Drill ditinjau dari Gaya Belajar
}

\author{
Cici Fransiska1, Ruhban Masykur'1, Fredi Ganda Putra1 \\ ${ }_{1}$ Universitas Islam Negeri Raden Intan Lampung. Jalan Endro Suratmin, Sukarame, Bandar \\ Lampung 35133, Indonesia. \\ *Corresponding Author. E-mail: chika.matematika@gmail.com
}

\begin{abstract}
Abstrak
Penelitian ini bertujuan untuk mengetahui perbedaan Metode Drill terhadap kemampuan pemecahan masalah matematis peserta, perbedaan peserta didik dengan gaya belajar visual, auditorial atau kinestetik terhadap kemampuan pemecahan masalah dan interaksi antara metode pembelajaran dengan gaya belajar peserta didik terhadap kemampuan pemecahan masalah matematis. Metode yang digunakan adalah metode Quasy Experiment, penelitian ini menggunakan teknik analisis varians (ANAVA) dua jalan dengan sel tak sama. Teknik pengumpulan data dilakukan dengan cara observasi, wawancara, dokumentasi dan metode angket. Hasil penelitian menunjukkan bahwa terdapat perbedaan Metode Drill terhadap kemampuan pemecahan masalah matematis peserta didik, tidak terdapat perbedaan gaya belajar visual, auditorial dan kinestetik terhadap kemampuan pemecahan masalah matematis dan tidak terdapat interaksi antara metode pembelajaran dan gaya belajar peserta didik terhadap kemampuan pemecahan masalah matematis, hal ini disebabkan karena metode pembelajaran (Metode Drill dan pembelajaran langsung) dan gaya belajar peserta didik memberikan efek yang sama terhadap kemampuan pemecahan masalah matematis.
\end{abstract}

Kata kunci: Gaya Belajar, Kemampuan Pemecahan Masalah, Metode Drill.

\begin{abstract}
This study aims to determine the differences in the Drill method of mathematical problem solving abilities of participants, differences in students with visual, auditory or kinesthetic learning styles on problem solving abilities and interactions between learning methods and learners' learning styles on mathematical problem solving abilities. The method used is the Quasy Experiment method, this study uses analysis of variance (ANAVA) two ways with unequal cells. Data collection techniques are carried out by observation, interviews, documentation and questionnaire methods. The results showed that there were differences in the Drill Method towards students 'mathematical problem solving abilities, there was no difference in visual, auditory and kinesthetic learning styles towards mathematical problem solving abilities and there was no interaction between learning methods and learners' learning styles towards mathematical problem solving abilities, $p$. this is because learning methods (Drill methods and direct learning) and learning styles of students have the same effect on mathematical problem solving abilities.
\end{abstract}

Keywords: Drill Method, Learning Style, Problem Solving Ability

\section{PENDAHULUAN}

Pemecahan masalah dalam matematika dipandang sebagai hal dasar yang sangat penting dimiliki setiap siswa, seorang anak yang ingin mencapai hasil belajar pada mata pelajaran matematika diperlukan proses kerja untuk memecahkan masalah matematika, dan memerlukan peran kerja memori. Hal ini didasarkan pada pemikiran bahwa materi matematika merupakan materi yang abstrak. Jenis materi ide abstrak ini memiliki karakteristik yang berbeda dengan materi ilmu lainnya. Dalam hal ini, matematika menuntut penalaran dalam mempelajarinya (B. Uno, 2012)

Berdasarkan hasil observasi pra survey di MTs Al-Muhajirin Panjang pada guru mata pelajaran matematika kelas VII, diperoleh bahwa peserta didik masih 
mengalami kesulitan karena masih menganggap bahwa pelajaran matematika adalah mata pelajaran yang susah. Metode yang dilakukan dalam pembelajaran matematika adalah metode yang berpusat pada guru dengan menggunakan metode konvensional, dalam mengerjakan soal matematika peserta didik masih berpatokan pada rumus matematika karena terbiasa menghafal, sehingga peserta didik tidak biasa mengerjakan soal tanpa mengingat rumus tersebut. Berdasarkan pengamatan awal, dari 147 peserta didik kelas VII yang ada di MTs AlMuhajirin Panjang terdapat 46 siswa yang memperoleh nilai $\geq 74$ dengan persentase $23,8 \%$ dan 101 siswa memperoleh nilai $\leq$ 74 dengan persentase 71, 42\%. Melihat masih banyak peserta didik yang memperoleh nilai dibawah rata-rata (KKM) ternyata kemampuan pemecahan matematis siswa masih rendah dalam proses pembelajaran matematika.

Berdasarkan hal itu bahwa pemecahan masalah matematis masih rendah. Salah satu faktor yang diduga mempengaruhi rendahnya kemampuan pemecahan masalah matematis peserta didik adalah metode pembelajaran yang digunakan oleh guru mata pelajaran matematika. Salah satu metode pembelajaran yang bagus digunakan adalah Metode Drill, yang merupakan suatu metode latihan yang berpusat pada peserta didik. Dengan demikian peserta didik menjadi lebih aktif dan tujuan pembelajaran akan tercapai dengan baik, terutama dalam hal pemecahan masalah matematis. Adapun tujuan Metode Drill adalah untuk lebih mengembangkan kemampuan pemecahan masalah matematis peserta didik. Selain metode pembelajaran, gaya belajar juga diduga mempengaruhi kemampuan pemecahan masalah. Gaya belajar adalah kombinasi dari bagaimana ia menyerap, dan kemudian mengatur serta mengolah informasi. (De Porter \& Hernacki, 1999). Dengan adanya gaya belajar, peserta didik dapat menyelesaikan masalah-masalah matematika berdasarkan gaya belajar mereka masing-masing. Peserta didik juga harus memahami jenis gaya belajarnya. Dengan demikian, ia telah memiliki kemampuan mengenal diri yang lebih baik dan mengetahui kebutuhannya.

Berdasarkan beberapa penelitian yang telah dilakukan sebelumnya Metode Drill banyak dilakukan dalam pelaksanaan pembelajaran karena memberikan pengaruh yang baik dalam pembelajaran (Erlinda, 2016; Jauhariyah \& Dardiri, 2017; Pambudi \& Pramudana, 2016; Purnamasari, Isman, Damayanti, \& Ismah, 2017; Rachmawati, Dwiantoro, \& Warsito, 2017) serta beberapa penelitian dalam meningkatkan kemampuan pemecahan masalah matematis siswa (Afryany \& Masrukan, 2015; Agoestanto, Arief, \& Safitri, 2013; Astriyani, 2016; Faelasofi, Arnidha, \& Istiani, 2015; Fitri, 2011; Imamah \& Toheri, 2014; Komala, 2012; Kusumawati, 2014; Laksana, Rochmad, \& Kharis, 2014; Mariya, Mastur, \& Pujiastuti, 2013; Muslim, 2017; Ngaeni \& Saefudin, 2017; Putra, 2017; Ramadhani, 2017; Susanti, Musdi, \& Syarifuddin, 2017; Syazali, 2015; Yustianingsih, Syarifuddin, \& Yerizon, 2017). Namun, belum adanya penelitian yang menerapkan Metode Drill terhadap kemampuan pemecahan masalah matematis ditinjau dari gaya belajar.

Keterbaruan penelitian ini terletak pada penggunaan Metode Drill terhadap kemampuan pemecahan masalah matematis ditinjau dari gaya belajar. Maka, tujuan penelitian ini adalah untuk mengetahui perbedaan Metode Drill terhadap kemampuan pemecahan masalah matematis peserta, perbedaan peserta didik dengan gaya belajar visual, auditorial atau kinestetik terhadap kemampuan pemecahan masalah dan interaksi antara metode pembelajaran dengan gaya belajar peserta 
didik terhadap kemampuan pemecahan masalah matematis.

\section{METODE PENELITIAN}

Metode yang digunakan adalah metode quasi experiment (eksperimen semu). Penelitian dilakukan pada kelas VII MTs Al-Muhajirin Panjang. Teknik sampel pada penelitian ini adalah dengan acak kelas. Teknik pengumpulan data menggunakan teknik observasi, wawancara, dokumentasi dan metode angket. Instrumen penelitian yang digunakan yaitu tes kemampuan pemecahan masalah matematis. Instrumen tes dalam penelitian meliputi Uji Validitas, Reliabilitas, Tingkat Kesukaran dan Daya Beda. Teknik Analisa Data dalam penelitian ini menggunakan Teknik analisa data yaitu teknik analisis varians (ANAVA) dua jalur. Sebelum menguji hipotesis terlebih dahulu dilakukan uji prasyarat, yaitu Uji Normalitas dan Uji Homogenitas. Untuk Uji Normalitas suatu data dapat menggunakan metode liliefors dengan taraf signifikan $(\alpha)$ : 0,05 dan hipotesis uji yaitu:

$\mathrm{H}_{0}$ : sampel berasal dari populasi yang berdistribusi normal

$\mathrm{H}_{1}$ : sampel tidak berasal dari populasi yang berdistribusi normal

Dengan Daerah kritis DK $=\{\mathrm{L} \mid$ Lhitung $>$ $\left.L_{\alpha ; n}\right\} ; \mathrm{n}$ adalah ukuran sampel, Keputusan uji yaitu, $\mathrm{H}_{0}$ ditolak jika Lhitung terletak di daerah kritik.

Uji homogenitas dilakukan untuk mengetahui apakah variansi-variansi dari sejumlah populasi sama atau tidak. Penelitian ini menggunakan uji Bartlett, yaitu menggunakan rumus:

$\left\{\chi^{2}=\frac{2.303}{c}\left(\mathrm{f} \log \mathrm{RKG}-\sum f_{j} \log s_{j}^{2}\right)\right.$

dengan $\chi_{\text {tabel }}^{2}=\chi_{(\alpha, k-1)}^{2}$

Hipotesis dari uji Bartlett adalah sebagai berikut:

$\mathrm{H}_{0}$ : Sampel berasal dari data homogen $\mathrm{H}_{1}$ : Sampel berasal dari data yang tidak homogen
Kriteria penarikan kesimpulan untuk uji Barlett jika $\chi_{\text {hitung }}^{2} \leq \chi_{\text {tabel }}^{2}$ maka $\mathrm{H}_{0}$ diterima.

Jika persyaratan homogenitas variansi populasi dipenuhi maka dapat dilakukan uji hipotesis menggunakan uji analisis variansi (ANAVA) dan jika homogenitas populasi tidak dapat terpenuhi peneliti tidak diperkenankan menggunakan uji analisis variansi.

\section{Analisis Data Akhir (Uji Hipotesis)}

Data yang telah diperoleh berdistribusi normal (parametrik), maka dapat menggunakan uji Anava dua jalan. Uji anava dua jalan adalah untuk melakukan uji beda rataan pada beberapa populasi secara serentak. Analisis data menggunakan teknik anava dua jalan dengan sel tak sama. Model datanya dapat dinyatakan sebagai berikut:

$X_{i j k}=\mu+\alpha_{i}+\beta_{j}+(\alpha \beta)_{i j}+\varepsilon_{i j k}$,

Keterangan :

$X_{i j k}=$ Observasi pada subyek yang dikenai faktor A (metode kerja kelompok dan metode pemberian tugas (resitasi) terhadap kemampuan pemecahan masalah matematis) ke-i dan faktor $B$ (Gaya Belajar peserta didik) ke-j pada pengamatan ke-k

$\mu \quad=$ Rata-rata besar

$\alpha_{i} \quad=$ Efek baris ke-i pada variabel terikat, dengan $\mathrm{i}=1,2$

$\beta_{j} \quad=$ Efek kolom ke-j pada variabel terikat, dengan $\mathrm{j}=1,2,3$.

$(\alpha \beta)_{i j}=$ kombinasi efek baris ke-i dan kolom ke-j pada variabel terikat

$\varepsilon_{i j k},=$ Galat berdistribusi normal.

\section{Uji Komparasi Ganda}

Komparasi ganda adalah tindak lanjut dari analisis variansi karena hasil analisis variansi tersebut menunjukkan bahwa hipotesis nol ditolak. Untuk uji lanjutan setelah analisis variansi digunakan metode Scheffe karena metode tersebut akan menghasilkan 
Desimal, 2 (2), 2019 - 134

Cici Fransiska, Ruhban Masykur, Fredi Ganda Putra

beda rataan dengan tingkat signifikan yang kecil. Metode Scheffe untuk komparasi antar kolom adalah:

Keterangan :

$$
F_{i-j}=\frac{\left(\bar{x}_{i}-\overline{\bar{x}}_{j}\right)}{R K G_{\frac{1}{n_{i}}+\frac{1}{n_{j}}}}
$$

$F_{i-j}=$ nilai $\mathrm{F}_{\text {obs }}$ pada perbandingan kolom ke- $i$ dan baris ke- $j$

$\bar{x}_{i}=$ pada perbandingan kolom ke$i$

$\overline{\bar{x}}_{J} \quad=$ pada perbandingan kolom ke$j$

$\mathrm{RKG}=$ rataan perhitungan galat yang diperoleh dari perhitungan analisis variansi

$\mathrm{n}_{\mathrm{i}}=$ ukuran sampel kolom ke- $i$

$\mathrm{n}_{\mathrm{j}}=$ ukuran sampel kolom ke- $j$

\section{HASIL DAN PEMBAHASAN}

Data dalam penelitian ini meliputi data hasil uji coba instrument, data hasil kemampuan pemecahan masalah matematis, dan data gaya belajar matematika. Berikut ini diberikan uraian tentang data-data tersebut.

\section{A. Data Hasil Uji Coba Instrumen}

1. Hasil Uji Coba Tes Kemampuan Pemecahan Masalah Matematis

\subsection{Uji Validitas}

Berdasarkan hasil perhitungan validitas soal terhadap 10 butir soal yang diuji cobakan, menyatakan bahwa terdapat 2 item soal yang tergolong tidak valid ( $\mathrm{r}_{\text {Tabel }} 0.404$ ) yaitu item soal nomer 2 dan 3 Sedangkan 8 item soal tergolong valid ( $\mathrm{r}_{\text {Tabel }} 0.404$ ) yaitu item soal nomor $1,4,5,6,7$, 8, 9, 10.

1.2 Uji Reliabilitas

Uji reliabilitas 10 butir soal uji coba tes kemampuan pemecahan masalah matematis diperoleh nilai $r_{11}=0,727$ dengan nilai $r_{\text {tabel }}=0,404$. Berdasarkan hasil analisis tersebut dapat disimpulkan bahwa $r_{11} \geq r_{\text {tabel }}$ yaitu $0,727 \geq 0,404$ sehingga instrumen uji coba tes kemampuan pemecahan masalah matematis tersebut reliabel.

1.3 Uji Tingkat Kesukaran

Uji tingkat kesukaran pada penelitian ini bertujuan untuk mengetahui apakah soal yang diujikan tergolong sukar, sedang dan mudah. Berdasarkan hasil perhitungan tingkat kesukaran terhadap 10 butir soal yang diuji cobakan menunjukan terdapat 1 butir soal yang tergolong dalam tingkat kesukaran mudah (TK > 0,75 ) yaitu soal nomor 5 , dan 8 butir soal yang tergolong dalam tingkat kesukaran sedang $(0,7<$ $\mathrm{TK}<0,30$ ) yaitu soal nomor $1,2,3$, $4,6,8,9$, dan 10. Adapun dalam tingkat kesukaran sukar $(\mathrm{TK} \leq 0,30)$ yaitu butir soal nomor 7.

1.4 Uji Daya Pembeda

Uji daya pembeda pada penelitian ini bertujuan untuk mengetahui seberapa jauh kemampuan butir soal dapat membedakan antara peserta didik yang menjawab dengan benar dengan peserta didik yang tidak menjawab dengan benar. Berdasarkan perhitungan daya pembeda butir soal menyatakan bahwa terdapat 1 butir soal tergolong jelek sekali yaitu nomor 2, sedangkan 6 butir soal tergolong cukup yaitu butir soal nomor 1, 3, 5, 7, 8 dan 9 selebihnya ada butir soal yang tergolong baik terdapat 3 butir soal yaitu soal nomor 4, 6 dan 10 .

1.5 Kesimpulan Hasil Uji Coba Tes Kemampuan Pemecahan Masalah Matematis

Berdasarkan perhitungan validitas, reliabilitas, tingkat kesukaran soal, dan daya beda soal, maka 10 soal yang telah diuji cobakan peneliti mengambil 8 butir soal yaitu soal nomor $1,4,5$, 
Desimal, 2 (2), 2019 - 135

Cici Fransiska, Ruhban Masykur, Fredi Ganda Putra

$6,7,8,9$ dan 10. Soal - soal yang sudah diuji cobakan tersebut digunakan untuk pengambilan data nilai kemampuan pemecahan masalah matematis pada kelas eksperimen dan kelas kontrol.

2. Hasil Uji Coba Angket Gaya Belajar

2.1 Validitas Isi Uji Coba Angket Gaya Belajar

Berdasarkan uji validitas isi yang telah dilakukan oleh validator diperoleh hasil bahwa ke 60 soal valid, sehingga dapat digunakan semua dalam penelitian.

2.2 Konsistensi Internal Uji Coba Angket Gaya Belajar

Berdasarkan uji coba konsistensi internal angket gaya belajar, angket gaya belajar dibagi menjadi tiga kelompok yaitu kelompok audiotorial berjumlah 20 item, kelompok visual berjumlah 20 item, dan kelompok kinestetik berjumlah 20 item. Berdasrkan perhitungan yang telah dilakukan dengan menggunakan rumus korelasi product moment dari karl pearson pada taraf signifikan 5\% diperoleh 31 item angket yang konsisten, sebab rTabel 0.404, sedangkan 29 item angket tidak konsisten, sebab rTabel $<0.404$. Sehingga diperoleh 31 soal yang dapat digunakan dalam penelitian dan 29 tidak dapat digunakan.

2.3 Reliabilitas Uji Coba Angket Gaya Belajar

Hasil perhitungan reliabilitas butir angket, dengan menggunakan rumus $\mathrm{r}_{11}$, sehingga didapat $=0.826$, sedangkan $\mathrm{r}_{\text {Tabel }}=0.404$ sehingga rhitung $>r$ Tabel maka dapat disimpulkan bahwa butir angket reliabel yang artinya butir angket dapat untuk diuji cobakan.
2.4 Kesimpulan Hasil Uji Coba Angket Gaya Belajar

Berdasarkan hasil perhitungan validitas dan reliabilitas 30 butir angket gaya belajar diperoleh 31 butir angket gaya belajar yang valid dan reliabel. Angket gaya belajar yang digunakan yaitu angket nomor $1,3,5,7,8,13,15$, $16,17,20,21,24,25,26,28$, dan 29. Angket - angket yang sudah diuji cobakan tersebut digunakan untuk pengambilan data nilai angket kemandirian belajar pada kelas eksperimen dan kelas kontrol.

3. Data Skor Angket Gaya Belajar Matematika Peserta Didik

Data tentang gaya belajar matematika peserta didik diperoleh dari skor angket. Penggolongan gaya belajar matematika peserta didik didasarkan pada kecenderungan skor peserta didik pada tipe yang sesuai. Peserta didik yang memiliki skor tertinggi pada tipe tertentu menunjukan bahwa peserta didik tersebut tergolong tipe tertentu itu. Berdasarkan data yang telah terkumpul, kelompok kelas eksperimen terdapat 5 peserta didik dengan gaya belajar audiotorial, 20 peserta didik dengan gaya visual, dan 17 peserta didik dengan gaya kinestetik. Sedangkan pada kelompok kelas Kontrol terdapat 11 peserta didik dengan gaya belajar audiotorial, 12 peserta didik dengan gaya visual, dan 14 peserta didik dengan gaya belajar kinestetik.

\section{B. Pengujian Persyaratan Analisis Data}

1. Uji Prasyarat Anova

1.1 Uji Normalitas

Uji normalitas digunakan untuk mengetahui apakah sampel berasal dari populasi yang 
Desimal, 2 (2), 2019 - 136

Cici Fransiska, Ruhban Masykur, Fredi Ganda Putra

berdistribusi normal. Uji kemampuan pemecahan normalitas yang digunakan dalam penelitian ini adalah liliefors dengan taraf signifikan masalah matematis peserta didik dapat dilihat dalam Tabel 5\%. Hasil uji normalitas skor 1.

Tabel 1. Hasil Uji Normalitas

\begin{tabular}{lllll}
\hline Uji Normalitas & Lobs & $\mathbf{L}_{(\mathbf{0}, \mathbf{0 5} ; \mathbf{n})}$ & Keputusan & Kesimpulan \\
Kelompok Eksperimen & 0.135 & 0.107 & $\mathrm{H}_{0}$ diterima & Normal \\
Kelompok Kontrol & 0.143 & 0.137 & $\mathrm{H}_{0}$ diterima & Normal \\
Gaya Belajar Audiotorial & 0.212 & 0.108 & $\mathrm{H}_{0}$ diterima & Normal \\
Gaya Belajar Visual & 0.154 & 0.149 & $\mathrm{H}_{0}$ diterima & Normal \\
Gaya Belajar Kinestetik & 0.155 & 0.114 & $\mathrm{H}_{0}$ diterima & Normal \\
& & & & \\
\hline
\end{tabular}

Berdasarkan Tabel 1, untuk masingmasing sampel ternyata $\mathrm{L}_{\mathrm{obs}}<\mathrm{L}$ Tabel sehingga $\mathrm{H}_{0}$ diterima, berarti masing-masing sampel berasal dari populasi yang berdistribusi normal. 1.2 Uji Homogenitas

Uji homogenitas digunakan untuk mengetahui apakah sampel berasal dari populasi yang homogen. Uji homogenitas yang digunakan dalam penelitian ini dilakukan sebanyak dua kali yaitu antar baris (uji homogenitas kemampuan pemecahan masalah matematis peserta didik dilihat dari model pembelajaran), antar kolom (uji homogenitas kemampuan pemecahan masalah matematis peserta didik dilihat dari gaya belajar). Hasil uji homogenitas dapat dilihat pada Tabel 2 sebagai berikut.

Tabel 2. Hasil Uji Homogenitas

\begin{tabular}{lccccc}
\hline Sampel & $\mathbf{k}$ & $\mathbf{X}^{\mathbf{2}}$ obs & $\mathbf{X}^{\mathbf{2}} \mathbf{0 . 0 5} ; \mathbf{n}$ & Keputusan & Kesimpulan \\
Metode Pembelajaran & 2 & 0.424 & 3.481 & $\mathrm{H}_{0}$ diterima & Homogen \\
Gaya Belajar & 3 & 3.513 & 5.991 & $\mathrm{H}_{0}$ diterima & Homogen
\end{tabular}

Berdasarkan Tabel 2, dapat dilihat nilai $\mathrm{X}^{2}$ obs dari kelas yang diberi perlakuan model pembelajaran dan gaya belajar peserta didik kurang dari $\mathrm{X}^{2}(0.05 ; \mathrm{n})$ sehingga $\mathrm{H}_{0}$ diterima, berarti variansi-variansi populasi yang dikenai perlakuan model pembelajar dan variansi-variansi gaya belajar peserta didik berasal dari populasi homogen.

\section{Hasil Pengujian Hipotesis}

Penelitian ini menggunakan anava 2 jalan dengan Hasil perhitungan analisis varian dua jalan dengan sel tak sama disajikan dalam Tabel 3 sebagai berikut 
Desimal, 2 (2), 2019 - 137

Cici Fransiska, Ruhban Masykur, Fredi Ganda Putra

Tabel 3. Rangkuman Analisis Varian Dua Jalan dengan Sel Tak Sama

\begin{tabular}{lrrrrrl}
\hline \multicolumn{1}{c}{$\begin{array}{c}\text { Sumber } \\
\text { Keragaman }\end{array}$} & \multicolumn{1}{c}{ JK } & Db & \multicolumn{1}{c}{ KT } & F $_{\text {hitung }}$ & $\mathbf{F}_{\text {tab }}$ & Keputusan \\
Baris (A) & $11.918,736$ & 1 & 11918.745 & 20.568 & 4.113 & HoA ditolak \\
Kolom (B) & 3111.698 & 2 & 1555.849 & 2.684 & 3.259 & HoA diterima \\
Interaksi (AB) & $5.103,988$ & 2 & 1151.9895 & 1.988 & 3.259 & HoA diterima \\
Galat & $23.652,309$ & 36 & 579.48056 & & & \\
Total & $17.334,422$ & 41 & & & & \\
\hline
\end{tabular}

Berdasarkan Tabel 3 di atas dapat disimpulkan bahwa (1) Ada perbedaan efek antar baris terhadap Variabel terikat, atau dengan kata lain kedua metode pembelajaran memberikan pengaruh yang tidak sama terhadap kemampuan pemecahan masalah matematis.(2) Tidak ada perbedaan efek antar kolom terhadap variabel terikat, atau dengan kata lain ketiga kategori gaya belajar matematika peserta didik memberikan pengaruh yang sama terhadap kemampuan pemecahan masalah matematis.(3) Tidak ada interaksi baris dan kolom terhadap variabel terikat yaitu antara penggunaan metode pembelajaran dan gaya belajar matematika peserta didik terhadap kemampuan pemecahan masalah matematis .

\section{Pembahasan Hasil Analisis}

\section{Hipotesis Pertama}

Berdasarkan uji anava dua jalan dengan sel tak sama yang telah dilakukan diperoleh $\mathrm{F}_{\text {obs }}=20.568$, dan $\mathrm{F}_{\text {Tabel }}=4.113$, maka dapat dikatakan bahwa $\mathrm{F}_{\text {obs }}>\mathrm{F}_{\text {Tabel, }}$ sehingga $F_{\text {obs }}$ merupakan anggota daerah kritik. Karena $F_{\text {obs }}$ merupakan daerah kritik maka $\mathrm{H}_{0} \mathrm{~A}$ ditolak, ini berarti bahwa terdapat perbedaan kemampuan pemecahan masalah matematis peserta didik antara peserta didik yang diberi perlakuan Metode Drill dan peserta didik yang diberikan perlakuan model pembelajaran langsung (konvensional). Hal ini dapat dilihat dari Tabel 4.

Tabel 4. Rataan dan Rataan Marginal

\begin{tabular}{lllll}
\hline \multicolumn{1}{c}{ Gaya belajar } & Audiotorial & Visual & Kinestetik & $\begin{array}{l}\text { Rataan } \\
\text { Marginal }\end{array}$ \\
Metode & & & & 68.272 \\
Drill & 75.2 & 64.85 & 64.765 & 41.929 \\
Konvensional & 37.636 & 57.583 & 30.57 & \\
Rataan Marginal & 56.418 & 61.2165 & 47.6675 & \\
\end{tabular}

Berdasarkan rataan marginal pada Tabel 4, pada peserta didik yang diberikan perlakuan Metode Drill adalah 68.272 sedangkan pada peserta didik yang diberikan model pembelajaran langsung adalah 41.929, sehingga dapat disimpulkan bahwa kemampuan pemecahan masalah matematis peserta didik yang diberi perlakuan Metode Drill memiliki kemampuan pemecahan matematis yang lebih baik dari pada peserta didik yang diberi perlakuan model pembelajaran langsung. Hal ini disebabkan karena Metode Drill memiliki beberapa kelebihan, diantaranya mampu menciptakan suasana belajar aktif dan menyenangkan, dimana peserta didik di tuntut aktif pada saat pembelajaran berlangsung, dengan demikian peserta 
didik akan lebih mudah dalam menerima materi yang diajarkan oleh guru. Dengan demikian dapat diambil kesimpulan bahwa penggunaan Metode Drill menghasilkan kemampuan pemecahan masalah matematis lebih baik dari pada model pembelajaran langsung.

\section{Hipotesis Kedua}

Berdasarkan uji anova dua jalan dengan sel tak sama yang telah dilakukan diperoleh $\mathrm{F}_{\text {obs }}=2.684$, dan $\mathrm{F}_{\text {Tabel }}=3.259$, maka dapat dikatakan bahwa $\mathrm{F}_{\text {obs }}<\mathrm{F}_{\text {Tabel, }}$ sehingga $F_{\text {obs }}$ bukan merupakan anggota daerah kritik. Karena $\mathrm{F}_{\text {obs }}$ bukan anggota daerah kritik maka $\mathrm{H}_{0} \mathrm{~B}$ diterima, ini berarti tidak terdapat perbedaan kemampuan pemecahan masalah matematis peserta didik yang memiliki gaya belajar audiotorial, visual, maupun kinestetik. Berdasarkan penelitian yang telah dilakukan oleh penulis, hal ini disebabkan peserta didik kurang memahami gaya belajar yang dimilikinya, sehingga dapat disimpulkan bahwa gaya belajar matematika tidak berpengaruh terhadap kemampuan pemecahan masalah matematis peserta didik.

\section{Hipotesis Ketiga}

Berdasarkan uji anova dua jalan dengan sel tak sama yang telah dilakukan diperoleh $\mathrm{F}_{\text {obs }}=1.988$, dan $\mathrm{F}_{\text {Tabel }}=3.259$, maka dapat dikatakan bahwa $\mathrm{F}_{\text {obs }}<\mathrm{F}_{\text {Tabel, }}$ sehingga $F_{o b s}$ bukan merupakan anggota daerah kritik, maka $\mathrm{H}_{0} \mathrm{AB}$ diterima, ini berarti tidak ada interaksi antara metode pembelajaran dan gaya belajar matematika peserta didik terhadap kemampuan pemecahan matematis.

\section{SIMPULAN DAN SARAN}

Berdasarkan analisis data dan pengujian hipotesis yang telah dilakukan dapat disimpulkan bahwa terdapat perbedaan Metode Drill terhadap kemampuan pemecahan masalah matematis, tidak terdapat perbedaan gaya belajar visual, auditorial dan kinestetik terhadap kemampuan pemecahan masalah matematis, tidak terdapat interaksi antara metode pembelajaran dan gaya belajar peserta didik terhadap kemampuan pemecahan masalah matematis, hal ini disebabkan metode pembelajaran (Metode Drill dan pembelajaran langsung) dan gaya belajar peserta didik memberikan efek yang sama terhadap kemampuan pemecahan masalah matematis.

Berdasarkan kesimpulan peneliti menyarankan agar Metode Drill dapat digunakan sebagai alternatif dalam proses belajar mengajar serta untuk penelitian selanjutnya yaitu agar dapat mengkaji masalah dengan jangkauan yang lebih luas dan mencoba menggunakan model-model pembelajaran lain untuk memaksimalkan berbagai aspek dalam pembelajaran matematika

\section{DAFTAR PUSTAKA}

Afryany, L., \& Masrukan. (2015). Pembelajaran DSCI Dengan Asesmen Polya Untuk Meningkatkan Kemampuan Pemecahan Masalah Siswa Kelas VIII Materi Lingkaran. Unnes Journal of Mathematics Education, 4(1), 15-21.

Agoestanto, Arief, \& Safitri, S. N. (2013). Keefektifan Pembelajaran Matematika Mengacu Pada Missouri Mathematics Project Terhadap Kemampuan Pemecahan Masalah. Prosiding Seminar Nasional Matematika VII UNNES, 71-77.

Astriyani, A. (2016). Peningkatan Kemampuan Pemecahan Masalah Peserta Didik Dengan Penerapan Model Pembelajaran Problem Posing. Fibonacci: Jurnal Pendidikan Matematika Dan Matematika, 2(1), 23-30.

B. Uno, H. (2012). Model Pembelajaran Menciptakan Proses Belajar Mengajar yang Kreatif dan Efektif. Jakarta: PT Bumi Aksara.

De Porter, B., \& Hernacki, M. (1999). Quantum Learning: Membiasakan 
Belajar Nyaman dan Menyenangkan. Bandung: Kaifa.

Erlinda, Y. (2016). Upaya Meningkatkan Hasil Belajar Matematika Perkalia Bersusun Kesamping Melalui Metode Drill Bagi Anak Tunagrahita Ringan. Jurnal Konseling Dan Pendidikan, 4(3), 18-23.

Faelasofi, R., Arnidha, Y., \& Istiani, A. (2015). Metode Pembelajaran Mind Mapping untuk Meningkatkan Kemampuan Komunikasi Matematik Siswa Dalam Pemecahan Masalah Matematika. Jurnal E-DuMath, 1(2), 122-137.

Fitri, A. (2011). Pengembangan Perangkat Pembelajaran Statistika Dasar Bermuatan Pendidikan Karakter Dengan Metode Problem Based Learning. Jurnal PP, 1(2), 159-165.

Imamah, F. U., \& Toheri. (2014). Pengaruh Penggunaan Kombinasi Metode Pembelajaran Discovery Learning Dan Brain Storming Terhadap Kemampuan Pemecahan Masalah Pada Pokok Bahasan Himpunan. EduMa, 3(1), 120-137.

Jauhariyah, D., \& Dardiri. (2017). Pengaruh Penggunaan Metode Drill pada Materi Kalor Terhadap Hasil Belajar Fisika Siswa. Al-Biruni : Jurnal Ilmiah Pendidikan Fisika, 6(1), 37-45. Komala, E. (2012). Pembelajaran dengan Pendekatan Diskursif untuk Meningkatkan Kemampuan Pemecahan Masalah Matematis dan Self-Concept Siswa Sekolah Menengah Pertama. Tesis Pada SPS UPI. Tidak Dipublikasikan.

Kusumawati, S. W. (2014). Penerapan Model Pembelajaran SAVI Untuk Meningkatkan Keterampilan Pemecahan Masalah di Sekolah Dasar. JPGSD, 2(2), 1-10.

Laksana, R. A. T., Rochmad, \& Kharis, M. (2014). Keefektifan Model Pembelajaran STAD Disertai Permainan MAM Terhadap Kemampuan Pemecahan Masalah
Kelas X Materi Logaritma. Unnes Journal of Mathematics Education, 3(2), 126-131.

Mariya, D., Mastur, Z., \& Pujiastuti, E. (2013). Keefektifan Pembelajaran SAVI Berbantuan Alat Peraga Terhadap Kemampuan Pemecahan Masalah. Unnes Journal of Mathematics Education, 2(2), 41-47.

Muslim, S. R. (2017). Pengaruh Penggunaan Model Project Based Learning Terhadap Kemampuan Pemecahan Masalah Matematis Peserta Didik SMA. Supremum Journal of Mathematics Education (SJME), 1(2), 88-95.

Ngaeni, E. N., \& Saefudin, A. A. (2017). Menciptakan Pembelajaran Matematika yang Efektif Dalam Pemecahan Masalah Matematika Dengan Model pembelajaran Problem Posing. Jurnal Aksioma, 6(2), 264274.

Pambudi, P. S., \& Pramudana, J. (2016). Penerapan Pembelajaran Drill dan Bermain Terhadap Hasil Belajar Servis Bawah Dalam Permainan Bolavoli Pada Siswa Kelas VII SMPN 2 Banyuwangi. Jurnal Sportif, 2(2), 98110.

Purnamasari, M., Isman, J., Damayanti, A., \& Ismah. (2017). Upaya Meningkatkan Hasil Belajar Matematika Terhadap Konsep Bangun Ruang Materi Luas dan Volume Balok dan Kubus Menggunakan Metode Drill Sekolah SMP Islam Al-Ghazali Kelas VIII. Fibonacci: Jurnal Pendidikan Matematika Dan Matematika, 3(1), 45-52.

Putra, F. G. (2017). Eksperimentasi Pendekatan Kontekstual Berbantuan Hands On Activity (HoA) Terhadap Kemampuan Pemecahan Masalah Matematik. Al-Jabar: Jurnal Pendidikan Matematika, 8(1), 73-80. Rachmawati, N., Dwiantoro, L., \& Warsito, B. E. (2017). Pengaruh Metode Drill 
Desimal, 2 (2), 2019 - 140

Cici Fransiska, Ruhban Masykur, Fredi Ganda Putra

dalam Supervisi Klinis Terhadap Spiritual Care Perawat. Jurnal Ners Dan Kebidanan Indonesia, 5(2), 115122.

Ramadhani, R. (2017). Kemampuan Pemecahan Masalah Matematika Siswa SMA Melalui Guided Discovery Learning Berbantuan Autograph. $J P P M, 10(2), 72-81$.

Susanti, Musdi, E., \& Syarifuddin, H. (2017). Pengembangan Perangkat Pembelajaran Matematika Materi Statistik Berbasis Penemuan Terbimbing Untuk Meningkatkan Kemampuan Pemecahan Masalah Matematis Materi Statistika. Jurnal JNPM ( Jurnal Nasional Pendidikan Matematika ), 1(2), 305-319.

Syazali, M. (2015). Pengaruh Model Pembelajaran Creative Problem Solving Berbantuan Maple II Terhadap Kemampuan Pemecahan Masalah Matematis. Al-Jabar, 6(1), 91-98.

Yustianingsih, R., Syarifuddin, H., \& Yerizon. (2017). Pengembangan Perangkat Pembelajaran Matematika Berbasis Problem Based Learning (Pbl) Untuk Meningkatkan Kemampuan Pemecahan Masalah Peserta Didik Kelas VII. Jurnal JNPM ( Jurnal Nasional Pendidikan Matematika ), 1(2), 258-274. 